\title{
Estimation of genetic parameters for dairy traits using repeatability animal models based on test-day data for Alpine goat in Croatia
}

\author{
Marija Špehar ${ }^{1 *}$, Danijel Mulc ${ }^{1}$, \\ Zdravko Barać', Boro Mioč², Ante Kasap²
}

\author{
'Croatian Agricultural Agency, llica 101, 10000 Zagreb, Croatia \\ ${ }^{2}$ University of Zagreb, Faculty of Agriculture, Department of Animal Science \\ and Technology, Svetošimunska 25, 10000 Zagreb, Croatia \\ *Corresponding author: mspehar@hpa.hr
}

\section{Abstract}

The objective of this study was to estimate genetic parameters for daily milk yield (DMY), fat (FC), and protein content (PC) using 329.022 test-day records of 23.756 Alpine does. Single trait repeatability animal model was applied. Parity, litter size, season, and lactation stage (Ali-Schaeffer's curve) were fitted in the fixed, while herd, herd-test-day, permanent environment (within lactations) and additive genetic effect in the random part of the model. Variance components were estimated using Residual Maximum Likelihood Method in the VCE-6 program. Additive genetic effect explained $23 \%, 16 \%$ and $25 \%$ of DMY, FC and PC variability which is in general agreement with numerous previous reports for dairy goat breeds. Among the non-genetic effects, herd explained $24 \%, 12 \%$, and $9 \%$, herd-test-day $17 \%, 29 \%$, and $30 \%$, and permanent environment $16 \%, 3 \%$, and $5 \%$ of DMY, FC and PC variability, respectively. The estimated parameters and developed single trait repeatability test-day models will serve as a basic tool in BLUP based genetic evaluation of Alpine breed in Croatia.

\section{Key words: Alpine breed, dairy traits, genetic parameters, test-day model}

\section{Introduction}

Nutritional value of goat's milk and its numerous beneficial effects on human health are probably the main reasons for its ongoing increased consumption worldwide (Park, 1994; Haenlein, 2004; Selvaggi et al., 2014). According to the Annual report of the Croatian Agricultural Agency, there were approximately 65.000 goats in Croatia in 2017 , and $10 \%$ of them were encompassed by the national selection programme (CAA, 2017). The most numerous dairy goat population under selec- tion was Alpine breed (4.465 animals) which has been predominantly reared in in the north-western part of the country. Selection of dairy goats in Croatia from its earliest days up to now has been directed toward improvement of the economically important traits (milk yield, fat and protein content). These traits follow a "polygenic pattern of inheritance" and their expression is strongly influenced by the environmental effects. Age at kidding, parity, litter size, season of kidding, and management practices in herds are considered as the most important environmental sources of phenotypic 
variability in ruminants (Mavrogenis et al., 1989; Brežnik et al., 1997; Carnicella et al., 2008; Torres-Vázquez et al., 2009). The initial steps of genetic evaluation of dairy goats in Croatia with BLUP methodology started in 2009 (Gorjanc and Špehar, 2011) and new strategy of selection was announced in "Breeding programme for the goat populations" (Mioč et al., 2012). The genetic parameters are baseline for genetic evaluation with BLUP (Sullivan et al., 1986; Barillet, 2007). Genetic parameters for dairy traits have been reported for Alpine and Saanen goat breeds (Belichon et al., 1999; Muller et al., 2002; Morris et al., 2006; Valencia et al., 2007; Torres-Vázquez et al., 2010; Brito et al., 2011), dairy breeds in the USA (Majid et al., 1994; Wiggans et al., 2003; Montaldo et al., 2010), Slovenian and Norwegian dairy breeds (Brežnik et al., 1997; Andonov et al., 1998; Andonov et al., 2007). The genetic parameters for dairy traits have been also estimated in several local goat breeds such as Damascus goats (Mavrogenis et al., 1989), Jamunapari and Barbari goats (Kala and Prakash, 1990), Verata (Rabasco et al., 1993), and Jonica goats (Selvaggi and Dario, 2015). Taking into account importance of genetic parameters in genetic evaluation process, the objective of the study was to develop a testday model and use it to obtain the estimates of the genetic parameters of dairy traits in Alpine goats in Croatia.

\section{Material and methods}

Data set with test-day records for dairy traits (daily milk yield - DMY, fat content - FC, and protein content - PC) for the period from February 1998 to November 2017 was obtained from the central database of the Croatian Agricultural Agency. Dairy traits were determined following the ICAR guidelines (ICAR, 2011) using AT4 method. Prior to the inferential statistical analysis some of the original records were excluded or modified. The following were excluded: records collected after sixth parity, records collected before $5^{\text {th }}$ and after $305^{\text {th }}$ days in milk, and records collected in the herds with less than three does at the same test-day. Litters with three and four kids were treated as the same group of the litter size which was hereinafter referred to as $3+$. Season of kidding was defined as month within year. In order to "boost" frequency of some of the less frequent classes (below 30 records per season), few adjacent classes were joined together. In addition, the records of all the analysed traits (DMY, FC, and PC) had to be available within each test-day. DMY was restricted to be in the interval from $0.3 \mathrm{~kg}$ to $6.0 \mathrm{~kg}$ for DMY, while FC could vary from $1.0 \%$ to $7.0 \%$ and PC from $1.0 \%$ to $9.0 \%$. After editing, 329,022 test-day records were used in further analysis.

All the available ancestral information of the phenotyped animals was also obtained from the central database of the Croatian Agricultural Agency. After pruning of the uninformative animals, a total of 29,474 animals were included in the pedigree (Table 1). Animals with both parents known, animals with only one parent known, and founders accounted for $90.8 \%, 5.3 \%$, and $3.9 \%$ of the animals, respectively. The average number of progeny per sire and dam was 18.6 and 1.9, respectively.

TABLE 1. Pedigree structure

\begin{tabular}{l|l} 
Item & N \\
\hline Animals with records & 23,756 \\
\hline Non-base animals & 28,324 \\
\hline - both parents known & 26,769 \\
\hline - only sire known & 1,213 \\
\hline - only dam known & 342 \\
\hline Base animals & 1,150 \\
\hline Proportion of base animals (\%) & 3,9 \\
\hline Average number of progenies per sire & 18,6 \\
\hline Average number of progenies per dam & 1,9 \\
\hline Total number of animals & 29,474
\end{tabular}

The GLM procedure (SAS Inst. Inc., 2009) based on the Least Square Method was used to define the fixed part of the statistical model. The effects were included in the model based on three criteria: significance level ( $p$-value), degrees of freedom (df), and coefficient of determination $\left(R^{2}\right)$. Covariance components were estimated by Residual Maximum Likelihood (REML) method in the VCE-6 program package (Groeneveld et al., 2008). Test-day records $\left(\mathrm{y}_{\mathrm{ijk} \mathrm{mn}}\right)$ were modelled with the repeatability animal models (Eq. 1 for DMY and Eq. 2 for FC and $P C)$. 
$y_{i j k l m n}=\mu+P_{i}+L_{j}+S_{k}+\sum_{p=1}^{4} b_{i p} t_{p}+\sum_{p=1}^{4} b_{j p} t_{p}+f_{l}+f t d_{m}+a_{n}+p_{n i}+e_{i j k l m n}$ [1]

$y_{i j k l m n}=\mu+P_{i}+L_{j}+S_{k}+\sum_{p=1}^{4} b_{i p} t_{p}+f_{l}+f t d_{m}+a_{n}+p_{n i}+e_{i j k l m n}[2]$

Parity $\left(P_{i} ; i=1,2,3, \ldots, 6\right)$, litter size $\left(L_{j}=1,2,3\right)$, and season of kidding $\left(S_{k} ; k=1,2,3, \ldots, 76\right)$ were fitted as fixed class effects. The effect of lactation stage $\left(\mathrm{t}_{\mathrm{ijklmn}}\right)$ was treated as covariate and fitted as the Ali-Schaeffer lactation curve with four regression coefficients (Ali and Schaeffer, 1987). The curve was nested within parity and litter size for DMY and within parity for FC and PC. Transformations of the days in milk (Eq. 3) used as covariates in the Ali-Schaeffer's lactation curve are given in the following form:

$\mathrm{t}_{1}=\mathrm{t}_{\mathrm{j} k \mathrm{kmn}} / 305, \mathrm{t}_{2}=\left(\mathrm{t}_{\mathrm{j} \mathrm{kmmn}} / 305\right)^{2}, \mathrm{t}_{3}=\ln \left(305 / \mathrm{t}_{\mathrm{j} k \mathrm{kmn}}\right), \mathrm{t}_{4}=\left(\ln \left(305 / \mathrm{t}_{\mathrm{j} k \mathrm{kmn}}\right)\right)^{2}[3]$

The random effects in the model were: herd $\left(f_{j} ; \quad I=1,2,3, \ldots, 408\right)$, herd-test-day $\left(\mathrm{ftd}_{\mathrm{m}}\right.$; $\mathrm{m}=1,2,3, \ldots, 13220$ ), permanent environment ( $p_{n i}$; $n i=1,2,3, \ldots, 69226)$, and additive genetic effect ( $a_{n}$; $n=1,2,3, \ldots, 29474)$ ).

TABLE 2. Descriptive statistics for dairy traits and days in milk

\begin{tabular}{l|l|l|l|l|l} 
Trait & N & Mean & SD & Min & Max \\
\hline Daily milk yield (kg) & 329,022 & 2.31 & 1.05 & 0.30 & 6.00 \\
\hline Fat content (\%) & 328,657 & 3.47 & 0.91 & 1.00 & 9.00 \\
\hline Protein content (\%) & 328,830 & 3.10 & 0.49 & 1.05 & 7.00 \\
\hline Lactation stage & 329,022 & 149.8 & 69.0 & 5.0 & 305.0
\end{tabular}

Inferential statistical analysis regarding to the fixed part of the model was performed prior to the estimation of genetic parameters in order to develop an appropriate statistical model for

\section{Results and discussion}

Within the average of 150 milking days, does lactated on average $2.31 \mathrm{~kg}$ of DMY with $3.47 \%$ of FC and $3.10 \%$ of PC (Table 2). Higher average DMY (2.58 and $2.93 \mathrm{~kg} /$ day) was found by Milerski and Mareš (2001) and Ciappesoni et al. (2002) for Czech dairy breeds. Contrary, Brežnik et al. (1997) reported lower average DMY (1.98 kg) in Slovenian Saanen and Alpine goats. The average FC and PC are in agreement with the values obtained by other authors (Brežnik et al., 1997; Milerski and Mareš, 2001; Ciappesoni et al., 2002; Bagnicka et al., 2015). Alpine breed in the current study had higher FC and PC values than Saanen goats (3.24 $\%$, and $2.72 \%$ reported by Torres-Vázquez et al. (2009). On contrary, Analla et al. (1996) reported higher FC (5.4 \%) and PC (3.5 \%) in Spanish Murciano-Granadina goats. estimation of the genetic parameters. All effects included in the models were statistically significant and explained from $12.50 \%$ to $29.49 \%$ of variance (Table 3 ).

TABLE 3. Variance analysis explained by the fixed part of the model for dairy traits

\begin{tabular}{l|l|l|l} 
Model & DMY & FC & PC \\
\hline$R^{2}$ & 26.10 & 12.50 & 29.49 \\
\hline$D F$ & 114 & 106 & 106 \\
\hline$P_{i}$ & $<0.0001$ & 0.1329 & $<0.0001$ \\
\hline$L_{j}$ & $<0.0001$ & $<.0001$ & $<0.0001$ \\
\hline$S_{k}$ & $<0.0001$ & $<.0001$ & $<0.0001$ \\
\hline$b_{1 j}$ & 0.1055 & $<.0001$ & $<0.0001$ \\
\hline
\end{tabular}

\begin{tabular}{l|l|l|l} 
Model & DMY & FC & PC \\
\hline$b_{2 i}$ & 0.0014 & $<.0001$ & $<0.0001$ \\
\hline$b_{3 i}$ & 0.0005 & 0.0004 & $<0.0001$ \\
\hline$b_{4 i}$ & 0.5199 & 0.0201 & $<0.0001$ \\
\hline$b_{5 j}$ & 0.0003 & & \\
\hline$b_{6 j}$ & 0.0045 & & \\
\hline$b_{7 j}$ & 0.0001 & & \\
\hline$b_{8 j}$ & $<.0001$ & &
\end{tabular}

$R^{2}=$ coefficient of determination, $D F=$ degrees of freedom, $P_{i}=$ parity; $L_{j}=$ litter size, $S_{k}=$ season of kidding, $b_{1 i}-b_{41}=$ Ali-Schaeffer regression coefficients nested within parity, $b_{5 j}-b_{8 j}=$ Ali-Schaeffer regression coefficients nested within litter size 
The results pertaining to impact of non-genetic effects (parity, season, lactation stage, and litter size) on dairy traits, are in general agreement with previous reports for different goat populations (breeds): Damascus in Cyprus (Mavrogenis et al., 1984, 1989), Alpine and Saanen in France and Brazil (Boichard et al., 1989; Brito et al., 2011), Alpine in Croatia (Mioč et al., 2008; Klir et al., 2015), Jamunapari and Barbari in India (Kala and Prakash, 1990), Verata in Spain (Rabasco et al., 1993), Saanen in Mexico (Valencia et al., 2002, 2007), and dairy goats in Czech Republic (Milerski and Mareš, 2001; Ciappesoni et al., 2004).

Phenotypic variance for dairy traits was split into five variance components (Table 4) commonly used in quantitative genetic studies orientated to dairy traits. Estimated heritabilities for DMY, FC and $P C$ were $0.23,0.16$ and 0.25 , respectively.

Estimated heritability of DMY (0.23) is in agreement with those reported by Muller et al. (2002) for South African Saanen goats. Very similar to these estimates were those of Brežnik et al. (1997) in Slovenian dairy breeds (0.20) and by Pesce Delfino et al. (2011) in Maltese goat (0.21). There are also a plenty of other reports on this issue with estimates ranging from 0.17 to 0.40 (Mavrogenis et al., 1984, 1989; Boichard et al., 1989; Kala and Prakash, 1990; Rabasco et al., 1993; Schaeffer and Sullivan, 1994; Brežnik et al., 1997; Valencia et al., 2002; Bagnicka et al., 2004; Weppert and Hayes, 2004; Morris et al., 2006, Torres-Vázquez et al., 2009; Montaldo et al., 2010; Pesce Delfino et al., 2011; Rout et al., 2017).

The heritability for $F C(0.16)$ goes in line with that of Analla et al. (1996) and Brežnik et al. (1997). The former reported heritability of 0.16 and 0.14 , and the later 0.18 and 0.16 obtained with single and multi-trait models, respectively. There are also other reports with estimates ranging from 0.14 to 0.50 for different dairy goat populations (Boichard et al., 1989; Analla et al., 1996; Brežnik et al., 1997; Andonov et al., 1998; Bagnicka et al., 2004; Andonov et al., 2007). In their 'pseudo' multi trait analysis with different statistical models, Bagnicka et al. (2004) reported heritabilities from 0.278 to 0.318 , and from 0.214 to 0.243 for the first and the later lactations, respectively.

The heritability for PC (0.25) is in general agreement with previous reports on this issue (Boich- ard et al., 1989; Analla et al., 1996; Brežnik et al., 1997; Bömkes et al., 2004; Andonov et al., 2007). For example, Analla et al. (1996) reported 0.22 and 0.25, and Brežnik et al. (1997) 0.24 and 0.21 in the single and multi-trait analysis, respectively. Bagnicka et al. (2004) reported notably higher heritabilities for the first lactation (0.397 to 0.448), and somewhat lower for later lactations (0.276 to 0.310). It is very ungrateful to compare the estimates across the studies, primarily due to different statistical approaches applied and different structure of the analysed populations (e.g. connectedness between herds, recording scheme of the performance data, pedigree depth etc.). However, by comparing results among the studies, it is evident that lactation models tend to produce higher heritability than the test-day model.

TABLE 4. Estimates of variance components and ratios ( \pm standard errors) for dairy traits

\begin{tabular}{l|l|l|l} 
Item & DMY & FC & PC \\
\hline$\sigma_{a}^{2}$ & 0.22139 & 0.13020 & 0.053070 \\
\hline$\sigma_{p}^{2}$ & 0.15029 & 0.027559 & 0.010429 \\
\hline$\sigma_{f}^{2}$ & 0.23036 & 0.10132 & 0.018506 \\
\hline$\sigma_{h t d}^{2}$ & 0.16288 & 0.23795 & 0.062770 \\
\hline$\sigma_{e}^{2}$ & 0.18065 & 0.32386 & 0.065404 \\
\hline$h^{2}$ & $0.23 \pm 0.01$ & $0.16 \pm 0.003$ & $0.25 \pm 0.004$ \\
\hline$p^{2}$ & $0.16 \pm 0.004$ & $0.03 \pm 0.01$ & $0.05 \pm 0.001$ \\
\hline$f^{2}$ & $0.24 \pm 0.01$ & $0.12 \pm 0.01$ & $0.09 \pm 0.01$ \\
\hline$f t d^{2}$ & $0.17 \pm 0.004$ & $0.29 \pm 0.004$ & $0.30 \pm 0.01$ \\
\hline$e^{2}$ & $0.20 \pm 0.004$ & $0.40 \pm 0.01$ & $0.31 \pm 0.004$
\end{tabular}

DMY - daily milk yield; FC - fat content; PC - protein content; $\sigma_{a}^{2}$ - direct additive genetic variance; $\sigma_{p}^{2}$-permanent environmental variance; $\sigma_{f}^{2}$ - herd variance; $\sigma_{\text {htd }}^{2}$ - herd-test-day variance; $\sigma_{e}^{2}$ - residual variance; $h^{2}$ - direct heritability; $p^{2}$ - ratio for permanent environment effect; $f^{2}$ - ratio for herd effect; $f t d^{2}$ - ratio for common herd-test-day; $e^{2}$ - ratio for residual

The permanent environmental effect (within lactation) explained $16 \%, 3 \%$, and $5 \%$ of the phenotypic variance for DMY, FC and PC, respectively (Table 4). This effect captured the part of phenotypic variability due to animals' physical state within particular lactation (condition and health status). From the practical point of view, the obtained results suggest that procedures related to the well-being of the animal (nutrition, care, and 
handling of does) affect more t the yield than the chemical composition of milk (on the variance level). The herd effect explained $24 \%, 12 \%$, and $9 \%$, and herd-test-day $17 \%, 29 \%$, and $30 \%$ of the total phenotypic variance for DMY, FC, and PC, respectively. The obtained results pertaining to the herd effect are in line with that of Brežnik et al. (1997) and Andonov et al. (1998) who fitted herd effect in the random part of the model. In the study of Brežnik et al. (1997) the effect explained $30 \%$, $10 \%$, and $11 \%$ of the phenotypic variability for DMY, FC, and PC, respectively. In the study of Andonov et al. (1998) the effect explained $25 \%$ and $14 \%$ of the phenotypic variability for DMY and FC, respectively. In the present study, both - herd and herd test-day effects were included into the random part of the model. By simultaneously fitting them as random effects in the model, proportion of residual variance decreased in a great extent, while estimates of other random effects (additive genetic and permanent environment effect) changed negligibly. This was more or less expected according to the background theory (e.g. Mrode, 2014). The obtained proportions of residual variances for DMY, FC, and PC were $20 \%, 40 \%$, and $31 \%$, respectively. In both of the above mentioned studies, the herd test-day effect was not fitted in the statis- tical models which led to notably higher proportion of unexplained variability in their studies (Brežnik et al. (1997): $31 \%, 68 \%$, and $59 \%$ for DMY, FC, and PC, respectively; Andonov et al. (1998): $44 \%$ and $65 \%$ for DMY and FC, respectively).

\section{Conclusions}

The generalisation of genetic and non-genetic effects should always be performed with great caution, especially in studies that are particularly prone to the inferential flaws due to prevalence of unbalanced data. However, by taking into account the size of the analysed data and all the steps performed in the inferential statistical analysis, we think that the obtained results reflect 'true' parameters with a high dose of certainty. The compliance of our results with those obtained in the reported studies indicates substantial dose of similarity in phenotypic-genotypic architecture of the dairy goat populations under consideration. The estimated parameters and developed single trait repeatability test-day models will serve a basic tool in BLUP based genetic evaluation of Alpine breed in Croatia. The investigated model has a potential to be used on other dairy goat breeds in Croatia as well as in other countries with similar structure of dairy goat populations.

\section{Procjena genetskih parametara za svojstva mliječnosti alpina koza u Hrvatskoj primjenom modela s fiksnom regresijom}

\section{Sažetak}

Cilj ovog istraživanja bio je procijeniti genetske parametre za dnevnu količinu mlijeka (DKM), udio mliječne masti (UM) i udio proteina u mlijeku (UP) temeljem 329,022 fenotipskih zapisa na dan kontrole mliječnosti koza pasmine Alpina (ukupno 23,756). Pri procjeni genetskih parametara za svako pojedino svojstvo korišten je model životinja s ponovljenim mjerenjima za jedno svojstvo (engl. single-trait repeatability animal model). U fiksnom dijelu modela korišteni su redoslijed laktacije, veličina legla, sezona laktacije i stadij laktacije (Ali-Schaeffer-ova krivulja). U slučajnom dijelu modela korišteni su utjecaji: stada, testnog dana unutar stada, trajnih okolišnih čimbenika unutar redoslijeda laktacije i aditivnih genetskih učinaka. Komponente varijance procijenjene su metodom REML u programu VCE-6. Udjeli aditivne genetske varijance u ukupnoj fenotipskoj varijanci DKM, UM i UP bili su redom $23 \%$, 16 \% i $25 \%$, što je u suglasju s brojnim publiciranim heritabilitetima za ova svojstva kod mliječnih pasmina koza. Udio varijance negenetskih čimbenika za svojstva DKM, UM i UP bili su redom $24 \%$, 12 \%, i 9 \% za utjecaj stada, 17 \%, 29 \%, i 30 \% za utjecaj testnog dana unutar stada i 16 \%, 3 \% i 5 \% za utjecaj trajnih okolišnih čimbenika unutar laktacije. Procijenjeni parametri i razvijeni statistički modeli biti će korišteni u rutinskom genetskom vrednovanju alpskih koza za svojstva mliječnosti u Hrvatskoj. 
1. Ali, T.E., Schaeffer, L.R. (1987): Accounting for covariances among test day milk yields in dairy cows. Canadian Journal of Animal Science 67, 637-644.

https://doi.org/10.4141/cjas87-067

2. Analla, M., Jiménez-Gamero, I., Munozserrano, A., Seradilla, J.M., Falagán, A. (1996): Estimation of genetic parameters for milk yield and fat and protein contents of milk from Murciano-Granadina goats. Journal of Dairy Science 79, 1895-1898. https://doi.org/10.3168/jds.S0022-0302(96)76558-X

3. Andonov, S., Kovac, M., Kompan, D., Dzabirski, V. (1998): Estimation of covariance components for test day production in dairy goat. In: Proceedings of the $6^{\text {th }}$ World Congress on Genetics Applied to Livestock Production, Volume 24: Sheep and goats (fibre); sheep and goats (meat and milk); poultry; horses; buffaloes, Armidale. NSW, Australia, 11-16 January, 145-148.

4. Andonov, S., Odegard, J., Boman, I.A., Svendsen, M., Holme, I..., Adnoy, T., Vukovic, V., Klemetsdal, G. (2007): Validation of test-day models for genetic evaluation of dairy goats in Norway. Journal of Dairy Science 90(10), 4863-4871. https://doi.org/10.3168/jds.2006-626

5. Bagnicka, E., Distl, O., Hamann, H., Łukaszewicz, M. (2004): Heritabilities of and genetic correlations between the dairy traits in goats estimated in first vs later lactations. Animal Science Papers and Reports 22, 205-213.

6. Bagnicka, E., Hamann, H., Distl, O. (2015): Structure and the non-genetic and genetic effects on milk traits in Polish dairy goat population. Animal Science Papers and Reports 33 (1), 59-69.

7. Barillet, F. (2007): Genetic improvement for dairy production in sheep and goats. Small Ruminant Research 70, 60-75. https://doi.org/10.1016/j.smallrumres.2007.01.004

8. Belichon, S., Manfredi E., Piacere, A. (1999): Genetic parameters of dairy traits in the Alpine and Saanen goat breeds. Genetics Selection Evolution 31, 529-534. https://doi.org/10.1186/1297-9686-31-5-529

9. Boichard, D., Bouloc, N., Ricordeau, G., Piacere, A., Barillet, F. (1989): Genetic parameters for first lactation dairy traits in the Alpine and Saanen goat breeds. Genetics Selection Evolution 21, 205-215. https://doi.org/10.1186/1297-9686-21-2-205

10. Bömkes, D., Hamann, H., Distl, O. (2004): Estimation of genetic parameters for test day records of milk performance traits in German Improved Fawn. Archiv fur Tierzucht 47, 193-202. https://doi.org/10.5194/aab-47-193-2004

11. Brežnik, S., Kovač, M., Kompan, D., Malovrh, Š. (1997): Genetic and environmental parameters of test day for milk yield, fat, protein and lactose content of dairy goats. In: Proceedings of the 48th Annual Meeting of the EAAP, Vienna, Austria, 1997.

12. Brito, L.F., Silva, F.G., Melo, A.L.P., Caetano, G.C., Torres, R.A., Rodrigues M.T., Menezes, G.R.O. (2011): Genetic and environmental factors that influence production and quality of milk of Alpine and Saanen goats. Genetics and Molecular Research 10(4), 3794-3802. https://doi.org/10.4238/2011.december.14.9
13. CAA (2017): Annual report for 2016. Sheep and goats, Croatian Agricultural Agency, Križevci.

14. Carnicella, D., Dario, M., Ayres, M.C.C., Laudadio, V., Dario, C. (2008): The effect of diet, parity, year and number of kids on milk yield and milk composition in Maltese goat. Small Ruminant Research 77, 71-74. https://doi.org/10.1016/j.smallrumres.2008.02.006

15. Ciappesoni, C.G., Milerski, M., Přibyl, J. (2002): Parámetros productivos de cabras de la raza checa marrón de pelo corto. In: XXVII Jornadas Científicas y VI Jornadas Internacionales SEOC, 19-21 de septiembre Valencia (España), 819-825.

16. Ciappesoni, G., Přibyl, J., Milerski, M., Mareš, V. (2004): Factors affecting goat milk yield and its composition. Czech Journal of Animal Science 49 (11), 465-473. https://doi.org/10.17221/4333-CJAS

17. Gorjanc, G., Špehar, M. (2011): Selekcija mliječnih koza koristeći uzgojne vrijednosti I uvažavanje inbridinga. 11. savjetovanje uzgajivača ovaca i koza u Republici Hrvatskoj: zbornik radova. Hrvatska poljoprivredna agencija, Zagreb.

18. Groeneveld, E., Kovač, M., Mielenz, N. (2008): VCE User's guide and reference manual, Version 6.0.

19. Haenlein, G.F.W. (2004): Goat milk in human nutrition. Small Ruminant Research 51, 155-163. https://doi.org/10.1016/j.smallrumres.2003.08.010

20. ICAR (International Committee for Animal Recording) (2011): Guidelines approved by the General Assembly held in Riga, Latvia, on 31 May to 4 June 2010, Roma, 229-256.

21. Kala, S.N., Prakash, B. (1990): Genetic and phenotypic parameters of milk yield and milk composition in two Indian goat breeds. Small Ruminant Research 3, 475-484. https://doi.org/10.1016/0921-4488(90)90078-K

22. Klir, Ž., Potočnik, K., Antunović, Z., Novoselec, J., Barać, Z., Mulc, D., Kompan, D. (2015): Milk production traits from Alpine breed of goats in Croatia and Slovenia. Bulgarian Journal of Agricultural Science, 21(5), 1064-1068.

23. Majid, A.M., Cartwright, T.C., Yazman, J.A., Fitzhugh Jr, H.A. (1994): Performance of five breeds of dairy goats in southern United States. II. Lactation yield and curves. World Review of Animal Production 29, 29-37.

24. Mavrogenis, A.P., Constantinou, A., Louca, A. (1984): Environmental and genetic causes of variation in production traits of Damascus goats 2.Goat productivity. Animal Production 38, 99-104 https://doi.org/10.1017/S0003356100041398

25. Mavrogenis, A.P., Papachristoforou, C., Lysandrides, P., Roushias, A. (1989): Environmental and genetic effects of udder characteristics and milk production in Damascus goats. Small Ruminant Research 2, 333-343. https://doi.org/10.1016/0921-4488(89)90028-X

26. Milerski, M., Mareš, V. (2001): Analysis of systematic factors affecting milk production in dairy goat. Acta Universitatis Agriculturae et Silviculturae Mendelianae Brunensis 1, 43-50.

27. Mioč, B., Barać, Z., Pavić, V., Prpić, Z., Mulc, D., Špehar, M. (2012): Program uzgoja koza u Republici Hrvatskoj. (Breeding program for goat in Croatia). Hrvatski savez uzgajivača ovaca i koza, Zagreb. 
28. Mioč, B., Prpić, Z., Vnučec, I., Barać Z., Samaržija, D., Pavić, V. (2008): Factors affecting goat milk yield and composition. Mljekarstvo 58 (4), 305-313.

29. Montaldo, H.H., Torres-Hernandez, G., Valencia-Posadas, M. (2010): Goat breeding research in Mexico. Small Ruminant Research 89, 155-163. https://doi.org/10.1016/j.smallrumres.2009.12.039

30. Morris, C.A., Wheeler, M., Lanuzel, M. (2006): Genetic trend and parameter estimates for milk yield traits and kidding date in a Saanen goat herd in New Zealand. Journal of Agricultural Research 49, 175-181. https://doi.org/10.1080/00288233.2006.9513707

31. Mourad, M. (2001): Estimation of repeatability of milk yield and reproductive traits of Alpine goats under an intensive system of production in Egypt. Small Ruminant Research 42 (1), 1-4. https://doi.org/10.1016/S0921-4488(01)00214-0

32. Mrode, R.A. (2014): Linear models for the prediction of animal breeding values, third ed. CABI Oxfordshire, UK

33. Muller, C.J.C., Cloet, S.W.P., Schoeman, S.J. (2002): Estimation of genetic parameters for milk yield and milk composition of South African Saanen goats. In: Proceedings of the $7^{\text {th }}$ World Congress on Genetics Applied to Livestock Production, Montpellier, France. Institut National De La Recherche Agronomique (INRA); Paris, France; 2002.

34. Park, Y.W., Mahoney A.W., Hendricks, D.G. (1986): Bioavailability of iron in goat milk compared with cow milk fed anemic rats. Journal of Dairy Science 69, 2608-2615. https://doi.org/10.3168/jds.S0022-0302(86)80708-1

35. Pesce Delfino, R., Selvaggi, M., Celano, G.V., Dario, C. (2011): Heritability estimates of lactation traits in Maltese goat. World Academy of Science, Engineering and Technology 78, 666-668.

36. Pollott, G.E., Gootwine, E. (2001): A genetic analysis of complete lactation milk production in Improved Awassi sheep. Livestock Production Science 71, 37-47. https://doi.org/10.1016/S0301-6226(01)00239-1

37. Rabasco, A., Serradilla, J.M., Padilla, J.A., Serrano, A. (1993): Genetic and non-genetic sources of variation in yield and composition of milk in Verata goats. Small Ruminant Research 11, 151-161. https://doi.org/10.1016/0921-4488(93)90148-B

38. Rout, P.K., Matika, O., Kaushik, R., Dige, M.S., Dass, G., Singh, S.K. (2017): Estimation of genetic parameters and genetic trends for milk yield traits in Jamunapari goats in semiarid tropics. Small Ruminant Research 153, 62-65. https://doi.org/10.1016/j.smallrumres.2017.05.004

39. SAS Inst. Inc. (2009): SAS/STAT 9.2 User's Guide, Cary, NC: SAS Institute Inc.

40. Selvaggi, M., Laudadio, V., Dario, C., Tufarelli, V. (2014): Major proteins in goat milk: an updated overview on genetic variability. Molecular Biology Reports 41, 10351048. https://doi.org/10.1007/s11033-013-2949-9

41. Selvaggi, M., Dario, C. (2015): Genetic analysis of milk production traits in Jonica goats. Small Ruminant Research 126, 9-12 https://doi.org/10.1016/j.smallrumres.2015.03.017
42. Schaeffer, L.R., Sullivan, B.P. (1994): Genetic evaluation of dairy goats using test day yields. In: Proceedings of the 5th World Congress on Genetics Applied to Livestock Production. Guelph, ON, Canada, 1994. pp. 182-185. https://doi.org/10.1063/1.868305

43. Sullivan, B.P., Kennedy, B.W., Schaeffer, L.R. (1986): Heritabilities, repeatabilities and correlations for milk, fat and protein yields in goats. Journal of Dairy Science 69 (1), 100.

44. Torres-Vázquez, J.A., Valencia-Posadas, M., CastilloJuárez, H., Montaldo, H.H. (2009): Genetic and phenotypic parameters of milk yield, milk composition and age at first kidding in Saanen goats from Mexico. Livestock Science 126, 147-153. https://doi.org/10.1016/j.livsci.2009.06.008

45. Torres-Vázquez, J.A., Valencia-Posadas, M., Castillo-Juarez, H., Montaldo, H.H. (2010): Genetic and phenotypic trends for milk yield and milk composition traits of Saanen goats from Mexico. Revista Mexicana de Ciencias Pecurias 1 , 337-348.

46. Valencia, P.M., Dobler, L.J., Arbiza, S.I. (2002): Sources of environmental variation affecting lactation and preweaning growth characteristics in Saanen goats. Cuban Journal of Agricultural Science 36, 117-122.

47. Valencia, M., Dobler, J., Montaldo, H.H. (2007): Genetic and phenotypic parameters for lactation traits in a flock of Saanen goats in Mexico. Small Ruminant Research 68, 318-322. https://doi.org/10.1016/j.smallrumres.2005.11.017

48. Weppert, M, Hayes, J.F. (2004): Direct genetic and maternal genetic influences on first lactation production in four breeds of dairy goats. Small Ruminant Research 52, $173-$ 178. https://doi.org/10.1016/S0921-4488(03)00221-9

49. Wiggans, G., Hubbard, S.M., Wrigth, J.R. (2003): AIPL Goat Evaluation Description. Genetic Evaluation of Dairy Goats for Yield and Type. Available in: https://www.aipl.arsusda. gov/reference/goat/goatsfs.html (13 May 2019). 